\title{
DOŚWIADCZENIA I WNIOSKI Z WOJSKOWEGO WYKORZYSTANIA OBSZARU WIELKICH JEZIOR MAZURSKICH W XX W.
}

$\mathrm{W}$

części wschodniej województwa warmińsko-mazurskiego leży Kraina Wielkich Jezior Mazurskich. Jej główną cechą jest niespotykane skupienie dużych zbiorników wodnych. Linia tych jezior w czasie I i II wojny światowej przecinała drogi wiodące ze wschodu w głąb Rzeszy Niemieckiej, zmuszając wojska atakujące od wschodu do obejścia ich między Pregołą a Węgorzewem. Dla zabezpieczenia prawego skrzydła jezior mazurskich nie pozwalano zmniejszać powierzchni puszczy Piskiej. Ponadto dostrzegając operacyjne znaczenie jezior, obszar ten intensywnie fortyfikowano, wraz ze znajdującą się w punkcie centralnym twierdzą Boyen w Giżycku.

Przedmiotem artykułu jest przedstawienie doświadczeń i wniosków płynących z wojskowego wykorzystania obszaru Wielkich Jezior Mazurskich w XX w. Ze względów objętościowych autor zawarł tylko podstawowe fakty związane ze znaczeniem tego obszaru. Jednocześnie dla pogłębienia wiedzy odsyła do literatury podanej w przypisach i bibliografii.

Jeziora nabrały ponownie znaczenia w drugiej połowie 1944 r., kiedy to Niemcy rozpoczęli intensywne przygotowania do obrony, rozbudowując system fortyfikacji i licząc na to, że Wielkie Jeziora Mazurskie powstrzymają natarcie Armii Czerwonej. Ale charakter działań bojowych w 1945 r. różnił się zasadniczo od walk toczonych w 1914 r., gdyż wspomniana armia pozbawiła Niemców możliwości prowadzenia obrony czynnej w oparciu o tę przeszkodę naturalną. Po II wojnie światowej obszar jezior znalazł się w granicach Polski. Uznano wówczas, że większość fortyfikacji jest zbędna, ale nie do końca - wojsko przejęło poligon w Orzyszu oraz obiekty koszarowe w Węgorzewie i Giżycku, które wykorzystywane są po dzień dzisiejszy. 


\section{Obszar Wielkich Jezior Mazurskich w I wojnie światowej}

Główną cechą Krainy Wielkich Jezior, ciągnącej się południkowo na wysokości od 116 do 120 m n.p.m., jest niespotykane skupienie dużych zbiorników wodnych, które zajmują powyżej 15\% powierzchni obszaru, tj. około $310 \mathrm{~km}^{2}$. W tej grupie są największe jeziora kraju, takie jak Śniardwy, Niegocin czy Mamry oraz bardzo wiele mniejszych. Dodatkowym atutem wartości obronnej tych jezior jest połączenie dorzecza Pregoły z dorzeczem Wisły poprzez Węgorapę i Pisę․

Linia tych jezior, która do I wojny światowej znajdowała się w odległości półtora do trzech dni przemarszu od granicy z Rosją, przecinała drogi wiodące ze wschodu w głąb Prus Wschodnich, zmuszając do obejścia tych jezior między Węgorzewem i Pregołą, albo do obchodzenia z południa znajdującej się tam błotnisto-lesistej Puszczy Piskiej (Jańsborskiej). Ponadto na odcinku Ruciane-Szczytno urządzono w lasach szereg zapór z niewielkimi blokhauzami. Po odrzuceniu Rosjan w 1915 r. cała ta linia obronna została zmodernizowana i utrzymywana była w gotowości bojowej² .

Duże kompleksy leśne przetrwały od najdawniejszych czasów na obszarze rozciągającym się na wschód od Wielkich Jezior Mazurskich. Na północny-wschód od Gołdapi, na północnych krańcach strefy pojezierza, rozpościera się Puszcza Romincka (25 km długości i 8-15 km szerokości), która zamykała przeprawę w grupie jezior na drodze do Gołdapi. Wartość obronną wzmacniały znajdujące się na obrzeżach puszczy jeziora. Kolejne ważne ogniwo naturalnych przeszkód osłaniających obszar jezior stanowiła Puszcza Borecka, rozciągająca się na wschód od Giżycka, na obszarze obejmującym około $250 \mathrm{~km}^{2}$ terenu urozmaiconego wzgórzami morenowymi, wznoszącymi się do 205 m n.p.m. i wieloma głębokimi jeziorami, takimi jak Gołdapiwo czy Łaźno ${ }^{3}$. Na południowych krańcach jezior rozpościera się rozległa Puszcza Piska (35 km długości z północy na południe, $15-25 \mathrm{~km}$ ze wschodu na zachód) z dominacją w drzewostanie sosny i świerku. Jej powierzchnia wynosi około $1000 \mathrm{~km}^{2} \mathrm{z}$ licznymi jeziorami w głębi puszczy, m.in. Nidzkim, Bełdany czy Mokre ${ }^{4}$.

${ }^{1}$ G. RąKowski, Kraina Wielkich Jezior Mazurskich, Warszawa 1988, s. 6-7; S. SRokowski, Prusy Wschodnie - studium geograficzne, gospodarcze i społeczne, Gdańsk 1945, s. 44-47; IDEM, Jeziora i Moczary Prus Wschodnich, Warszawa 1930, s. 34; W.B. ŁACH, System obronny Prus Wschodnich (do 1935 roku), Olsztyn 1997, s. 14; R. Umiastowski, Geografia wojenna Rzeczypospolitej Polskiej i Ziem Ościennych, Warszawa 1924, s. 57.

2 S. SRokowski, Jeziora i Moczary..., s. 6-9.

${ }^{3}$ IDEM, Prusy Wschodnie - studium..., s. 85.

${ }^{4}$ L. Herz, Puszcza Piska, Warszawa 1984, s. 10. 
Kluczową rolę w systemie fortyfikacji Prus Wschodnich spełniały dzieła obronne, zbudowane na linii Wielkich Jezior Mazurskich. Była to najdalej na wschód wysunięta pozycja obronna oparta o naturalne przeszkody na odcinku od Węgorzewa do Pisza, wzmocniona przez zamknięcie umocnieniami wąskich przejść (przesmyków) między jeziorami. Zapora ta miała rozdzielić siły rosyjskie i umożliwić zniszczenie ich częściami ${ }^{5}$. Dodatkowo miała zabezpieczyć własne wojska $\mathrm{w}$ okresie koncentracji przed atakiem jazdy rosyjskiej i osłaniać pierwszy etap działań swych sił zbrojnych ${ }^{6}$.

Za najważniejszy punkt całej linii obronnej uważano przejście między jeziorami Kisajno i Niegocin w Giżycku (do 1945 r. Lötzen). W celu zamknięcia tego przesmyku, w kwietniu 1842 r. podjęto decyzję o budowie twierdzy Boyen położonej na zachód od miasta, na obszarze około 100 hektarów. Właściwe prace budowlane rozpoczęto w $1847 \mathrm{r}$. W celu wzmocnienia i osłony przejść przez kanały wzniesiono wokół twierdzy 23 wysunięte stanowiska oraz schrony dla artylerii i piechoty ${ }^{7}$. Wraz z rosnącym znaczeniem jezior mazurskich jako punktu centralnego w obronie Prus Wschodnich zaczęto tworzyć infrastrukturę koszarową i poligonową dla przybywających jednostek liniowych. Już w 1859 r. powstał w Giżycku stały garnizon wojskowy. Od następnego roku naprzemiennie stacjonowały w nim bataliony 43, 44, 45 Pułku Piechoty oraz 3 Pułku Grenadierów. Załogę twierdzy natomiast stanowił 2 Forteczny Oddział Karabinów Maszynowych wraz z dywizjonem 1 Pułku Artylerii Pieszej oraz 5 Oddziałem Karabinów Maszynowych ${ }^{8}$. Trwająca rozbudowa twierdzy spowodowała, iż na przełomie XIX i XX w. powstały w Giżycku nowe kompleksy koszarowe między dzisiejszą aleją 1 Maja i ul. Nowowiejską, gdzie stacjonowały pododdziały piechoty. Drugi kompleks współcześnie już nieistniejący, powstał przy ulicy Sikorskiego - określany mianem „koszar artyleryjskich”, gdyż od 1912 r. stacjonował tam dywizjon 82 Pułku Artylerii Polowej'.

W 1892 r. powstał projekt budowy for tyfikacji z wykorzystaniem linii jezior i lasów mazurskich. Składać się one miały z trzech odcinków ${ }^{10}$ : północnego (wzdłuż

${ }^{5}$ W.B. ŁACH, Wplyw fortyfikacji na kierunki działań operacyjno-taktycznych na froncie wschodnim $w$ czasie I wojny światowej, [w:] Fortyfikacje $w$ działaniach wojennych frontu wschodniego Wielkiej Wojny 1914-1915, red. R. KeMPA, Giżycko 2017, s. 14.

${ }^{6}$ W.B. ŁACH, System obronny..., s. 50.

7 Vide: R. Kempa, Twierdza Boyen w Giżycku. Przewodnik praktyczny, Giżycko 2012; W.B. ŁACH, System obronny..., s. 50-54; W. RużEwICz, Fortyfikacje Nowożytne Prus Wschodnich - przewodnik, Łódź 2006, s. 161-183. Nazwa twierdzy została nadana na cześć pruskiego ministra wojny feldmarszałka von Boyena, który był inicjatorem jej budowy.

${ }^{8} 15$ Giżycka Brygada Zmechanizowana im. Zawiszy Czarnego 1994-2016, red. R. KempA, A. ProKOPCZuK, Giżycko 2016, s. 69.

9 Ibidem, s. 70-71.

${ }^{10}$ W.B. ŁACH, System obronny..., s. 54; K. KLECZKe, W. Wyszyński, Fortyfikacja stała, Warszawa 1937, s. 108. 
Węgorapy), właściwej fortyfikacji linii jezior oraz południowego (obejmującego tzw. fortyfikacje leśne). Przedłużeniem linii obronnej była Puszcza Piska (jańsborska) której obronna rola została zwiększona przez rozbudowę linii umocnień na odcinku od Rucianego (obecnie Ruciane-Nida) do Szczytna ${ }^{11}$.

W 1890 r. podjęto decyzję o utworzeniu poligonu w Orzyszu, na co wpływ miało kilka czynników, w tym zwłaszcza: niewielka gęstość zaludnienia i położenie przyszłego poligonu wśród lasów i jezior, w pobliżu rosyjskiej granicy. Dzięki temu, panowały tu warunki klimatyczne bliskie tym, w jakich żołnierzom przyszłoby walczyć na froncie wschodnim. Nie bez znaczenia była także dostępność linii komunikacyjnych - dróg bitych i kolejowych, które stwarzały możliwość dalszej rozbudowy. Budowa trwałych obiektów dla wojska w 1895 r. sprawiła, że Orzysz otrzymał status miasta garnizonowego. W pierwszej dekadzie XX w. zbudowano 110 murowanych budynków koszarowych, w których w 1908 r. można było zakwaterować około 300 oficerów, 12 tys. żołnierzy oraz 150 koni. Przybywali tu żołnierze powołani pod broń w całym Cesarstwie Niemieckim. Służba była uważana za ciężką, nie tylko z racji oddalenia od rodziny, ale i uciążliwych ćwiczeń na poligonie oraz surowego klimatu ${ }^{12}$. Trzeci garnizon powstał w Węgorzewie, gdzie kompleks koszarowy zbudowano na początku XX w. (przy obecnej ulicy gen. Józefa Bema) - przeznaczony został dla 10 Pułk Jegrów Konnych, którzy stacjonowali w nim w latach 1913-1919 ${ }^{13}$.

Bitwa na linii jezior mazurskich we wrześniu 1914 r. zakończyła się sukcesem niemieckiej 8 Armii. Nie był to sukces pełny, bowiem pierwotnie zakładano okrążenie i zniszczenie rosyjskiej 1 Armii poprzez manewr dwustronnego oskrzydlenia. Na plus stronie niemieckiej zaliczyć można dobrą orientację w terenie i rozpoznanie działań przeciwnika oraz umiejętne wykorzystanie artylerii polowej, w tym artylerii z twierdzy Boyen ${ }^{14}$. Po zakończeniu bitwy, niemiecka 8 Armia przystąpiła do budowy silnych umocnień ziemnych wzdłuż rzeki Dejmy, Węgorapy oraz w obszarze jezior mazurskich. Filarem tej polowej pozycji obronnej była w dalszym ciągu twierdza Boyen. Dla jej wsparcia wzniesiono nowe, polowe punkty oporu na linii od jeziora Śniardwy po jezioro Święcajty na północy (front wschodni) oraz Dejguny-Ryńskie (front zachodni). Ta nowa pozycja obrony nazwana została Giżycką Pozycją Polową ${ }^{15}$. Okazały się one potrzebne, bo już na

11 W.B. ŁACH, Umocnienia południowego odcinka Wielkich Jezior Mazurskich w Prusach Wschodnich w latach I wojny światowej, „Znad Pisy” 1999, nr 8, s. 66-67.

${ }^{12}$ W. Brenda, Militarne dzieje ziemi piskiej w XX wieku, [w:] Dzieje militarne Krainy Wielkich Jezior Mazurskich, red. W.B. ŁACH, D. RADZIwIŁŁowicz, S. JANOwICZ, Wilkasy 2013, s. 135-136.

${ }^{13}$ M. Ziniewicz, Wojskowa infrastruktura techniczna z czasów I wojny światowe obecnie wykorzystywana przez resort obrony narodowej, [w:] Wielka wojna na Mazurach. Studia z dziejów frontu wschodniego I wojny światowej, red. R. KEMPA, Giżycko 2014, s. 429-430.

${ }^{14}$ W.B. ŁaCH, System obronny..., s. 111.

${ }^{15}$ R. Kempa, Giżycka Pozycja Polowa (wrzesień 1914 - luty 1915), „Feste Boyen” 2005, z. 8, s. 65. Łącznie wzniesiono tu 38 punktów oporu. Na froncie zachodnim wzniesiono 12 punktów oporu. Punkty 
początku listopada 1914 r. do Prus Wschodnich ponownie zbliżały się wojska rosyjskie. Nowo zorganizowana i wzmocniona świeżymi siłami rosyjska $10 \mathrm{Ar}$ mia, po początkowych sukcesach - utknęła 12 listopada na umocnieniach wybudowanych przez Niemców na Szeszupie i Węgorapie oraz na zaporach wodnych i leśnych ciągnących się od jeziora Mamry, poprzez twierdzę Boyen, do jeziora Nidzkiego. Front na tej linii się ustabilizował, a walki przybrały charakter walk pozycyjnych, które ze zmiennym szczęściem toczyły się do końca grudnia 1914 r. $^{16}$

Fortyfikacje Prus Wschodnich zostały jeszcze wykorzystane w tzw. Bitwie Zimowej na Mazurach w styczniu-lutym 1915 r. tworząc podstawę wyjściową do przygotowania nowej ofensywy przeciw wojskom rosyjskim. Analogicznie jak w sierpniu 1914 r., tak i obecnie, dowództwo niemieckie liczyło, że linia fortyfikacji jezior mazurskich będzie tworzyła podstawę, która przyczyni się do skutecznego zrealizowania zaplanowanego natarcia i zniszczenia przeciwnika.

Dnia 10 lutego 1915 r., Niemcy, wykorzystując moment wycofywania Rosjan, rozpoczęli działania zaczepne w kierunku na Olecko, czym zaskoczono zajmującą tam pozycję rosyjską 10 Armią (zwłaszcza w rejonie Pisza). W tej sytuacji południowe skrzydło armii rosyjskiej rozpoczęło się wycofywać na wschód od linii kolejowej Ełk-Olecko uniemożliwiając wykonanie oskrzydlenia oddziałom niemiecki. Niemcy odzyskali całe terytorium Prus Wschodnich. Po zakończeniu walk zimowych na jeziorach mazurskich wiosną 1915 r., większość istniejących polowych punktów oporu wzmocniono fortyfikacjami stałymi, budując $\mathrm{w}$ ten sposób nową pozycję obronną pod nazwą Giżycka Pozycja Polowa (Loetzener Feldstellung). Składała się ona $\mathrm{z}$ betonowych schronów wkomponowanych w system fortyfikacji polowych. Wiele powstało również na przedpolu systemu jezior mazurskich, pomiędzy mniejszymi, rozproszonymi jeziorami ${ }^{17}$.

Wielkie Jeziora Mazurskie stały się przykładem wykorzystania naturalnych walorów obronnych, stając się podstawą niemieckiego planu wojny w odniesieniu do Prus Wschodnich. Wobec możliwości jednoczesnego działania rosyjskiego od wschodu i od południa, nie można było jednak ograniczyć się do obrony biernej. Jedynym racjonalnym rozwiązaniem było wykorzystanie linii wewnętrznych i szybkie uderzenie na część sił nieprzyjaciela. Zaporą, która rozdzieliła siły rosyjskie i umożliwiła zniszczenie ich częściami stały się umocnienia jezior mazurskich ${ }^{18}$.

wznoszone były w rejonie wzgórz, na przesmykach między jeziorami. Schrony piechoty lokowano zwykle na przeciwzboczu, schrony pogotowia w centrum, a schrony obserwacyjne i wartownie na stokach.

${ }_{16}$ Ibidem, s. 66-67.

17 W.B. ŁACH, Działania militarne na obszarze Warmii i Mazur w 1914 roku i ich konsekwencje, [w:] Wielka wojna na Mazurach. Studia $z$ dziejów..., s. 188-189; R. KempA, op. cit., s. 72-73; W.B. ŁACH, Wpływ fortyfikacji..., s. 17-18; W. RużEwICZ, op. cit., s. 54-55 i 57-58. Zakrojone na szeroką skalę prace budowlane objęły już wcześniej sprawdzone w działaniach bojowych 38 punktów oporu na froncie wschodnim i 12 na zachodnim, które wzmocniono stałymi i polowymi obiektami fortyfikacyjnymi.

${ }^{18}$ W.B. ŁaCH, System obronny..., s. 63. 


\section{Wykorzystanie obszaru jezior mazurskich jako bazy wypadowej do działań zaczepnych przeciwko Polsce w 1939 r.}

Zawarty 28 czerwca 1919 r. traktat pokojowy z Niemcami przekreślił ich nadzieje na utrzymanie armii na poziomie zbliżonym do stanów sprzed I wojny światowej. Obok drastycznego ilościowo zmniejszenia niemieckich sił zbrojnych, wojskowe klauzule traktatu pokojowego wprowadzały szereg istotnych ograniczeń w zakresie budowy i posiadania fortyfikacji. Niemcy jednak nie zamierzały się podporządkować temu zakazowi i rozbudowywały fortyfikacje na pograniczu z Polską. Inwestycje rozpoczęte w 1920 r. oparto na wypracowanej w czasie wojny idei budowy fortyfikacji półstałej, mającej wzmocnić twierdzę Królewiec i Giżycko ${ }^{19}$.

Według oceny Oddziału II Sztabu Generalnego (SG) Wojska Polskiego (WP), teren Prus Wschodnich pod względem przydatności do obrony został podzielony przez dowództwo okręgu Królewiec na cztery obszary ${ }^{20}$. Obszar trzeci obejmował pasmo Wielkich Jezior Mazurskich wraz z innymi przeszkodami, mogącymi służyć za granicę dla oddziałów osłony. Kolejnym jego przeznaczeniem było spełnienie roli pierwszego pasa fortyfikacji wobec całego systemu umocnień Prus Wschodnich. Umocnienia te usytuowane były wzdłuż jezior mazurskich od Puszczy Piskiej do Puszczy Rominckiej - z myślą o stworzeniu rejonu umocnionego ${ }^{21}$.

Fortyfikacje jezior mazurskich o długości około $150 \mathrm{~km}$ zostały podzielone $\mathrm{na}^{22}$ : rejon twierdzy Boyen wraz z przedpolem, odcinek Giżycko-Ruda-Okartowo - pierwsza linia oporu, odcinek Giżycko-Szymonka-Mikołajki - druga i główna linia oporu, odcinek Mikołajki-Ryn-Martiany-Doba - zamykający rejon od zewnątrz oraz odcinek Mikołajki-Ruciane - stanowiący przedłużenie umocnień i połączenie z pozycją leśną. Najsłabszy odcinek tworzyła zachodnia część umocnień oparta o Mikołajki, Ryn i Dobę. Fortyfikacje stałe nie były modernizowane i konserwowane, nie było tu także trudniejszych do sforsowania naturalnych przeszkód. Odcinek Mikołajki-Ruciane był przedłużeniem systemu umocnień leśnych. Można go było pokonać, przełamując przesmyki międzyjeziorne w Rucianem i Guziance. Jednak były one silnie umocnione i posiadały korzystne warunki do flankowania i obserwacji ${ }^{23}$.

19 Ibidem, s. 125-126,

20 Ibidem, s. 132-136; J. BocHenek, System fortyfikacji stałych $w$ świetle doświadczeń wojny, „Bellona” 1945, t. VII, s. 351-352; M. Rogalski, M. Zвorowski, Fortyfikacja wczoraj i dziś, Warszawa 1978, s. 95-96; Centralne Archiwum Wojskowe w Wojskowym Biurze Historycznym (CAW-WBH), Genealny Inspektorat Sił Zbrojnych (GISZ), Inspektorat Armii Toruń, sygn. I.302.7.6, Prusy Wschodnie. Opis wojskowo-geograficzny (wydanie tymczasowe), Warszawa 1924, brak paginy.

${ }^{21}$ CAW-WBH, GISZ, Inspektorat Armii Toruń, sygn. I.302.7.6, Prusy Wschodnie. Opis wojskowo-geograficzny (wydanie tymczasowe), Warszawa 1924, brak paginy.

${ }^{22}$ W.B. ŁACH, Polska północna w systemie obronnym kraju w latach 1918-1926, Olsztyn 2010, s. 215.

${ }^{23}$ IDEM, Umocnienia południowego..., s. 66-67. 
W latach trzydziestych Niemcy, wykorzystując luki w postanowieniach traktatu wersalskiego oraz ogólne osłabienie kontroli, przystąpili do dalszej rozbudowy umocnień. Rozpoczęto intensywne prace fortyfikacyjne obejmujące około jednej trzeciej całego obszaru Prus Wschodnich ${ }^{24}$. Dzięki temu - w dniu wybuchu II wojny światowej - ich stan fortyfikacji był zróżnicowany i składał się z ośmiu rejonów i pozycji umocnionych, w składzie których znajdował się Rejon Umocniony Giżycko (Befestiger Raum Lötzen) obejmujący obszar Wielkich Jezior Mazurskich. Składał się on z obiektów fortyfikacyjnych sprzed I wojny światowej, uzupełnionych w latach 1924-1939 o nowe obiekty. Betonowe schrony bojowe usytuowane były w jednej linii, a na ważniejszych kierunkach w 2-3 liniach, o gęstości 5-7 schronów na kilometr frontu ${ }^{25}$.

W latach 1921-1933 jedyną liniową formacją Reiswehry w pasie Wielkich Jezior Mazurskich był stacjonujący w Giżycku III batalion 2 Pułku Piechoty 1 Dywizji Piechoty oraz Komenda Fortyfikacji (Kommandantur der Befestigungenbeil Lötzen). Dojście Hitlera do władzy zapoczątkowało szybki proces rozbudowy armii. W latach 1935-1936 wybudowano dwa nowe kompleksy koszarowe: przy dzisiejsze ulicy Wojska Polskiego, gdzie stacjonował 11 Batlion Saperów oraz przy ulicy Moniuszki, gdzie przeniósł się 2 Zmotoryzowany Dywizjon 47 Pułku Artylerii ${ }^{26}$.

Uruchomiony ponowienie w $1921 \mathrm{r}$. poligon orzyski został w czerwcu $1935 \mathrm{r}$. powiększony do 20 tys. hektarów. W samym Orzyszu zmodernizowano stare koszary, nadając im nazwę Arys Nord. Natomiast w odległości $12 \mathrm{~km}$ na południe - w Szladze (dzisiejsze Bemowo Piskie) zbudowano nowoczesny obiekt koszarowy pod nazwą Arys Süd. W 1939 r. w Orzyszu stacjonowały dwa pułki piechoty oraz dywizjon artylerii, natomiast w Szladze - jeden pułk piechoty i dwa dywizjony artylerii ${ }^{27}$. Z kolei w Węgorzewie, stary znajdujący się po lewej stronie dzisiejszej ulicy gen. Józefa Bema kompleks koszarowy okazał się za mały. Dlatego też po drugiej stronie ulicy wybudowano nowy, w którym ulokowano 2 Pułk Kawalerii, wchodzący w skład trzypułkowej brygady kawalerii z siedzibą dowództwa w Instenburgu (Czerniachowsk) ${ }^{28}$.

Przygotowując plany związane $\mathrm{z}$ działaniami wojennymi wobec Polski, niemieccy sztabowcy postrzegali Prusy Wschodnie jako region, z którego można wyprowadzić uderzenie w kierunku przepraw przez Wisłę (Grudziądz) i północnego Mazowsza. Zadanie to przydzielono 3 Armii. Jej wschodnie skrzydło - oparte

${ }^{24}$ K. Dieckret, H. Grossman, Bój o Prusy Wschodnie. Kronika dramatu 1944-1945, Gdańsk 2011, s. 25.

${ }^{25}$ W.B. ŁACH, System obronny na Warmii i Mazurach $w$ czasie II wojny światowej, Węgorzewo 2002, s. 50; M. Rogalski, M. ZвOROWSKI, op. cit., s. 280-281.

${ }^{26} 15$ Gizycka Brygada..., s. 71-72.

${ }^{27}$ W. BRENDA, op. cit., s. 150.

${ }^{28}$ M. ZiniewiCZ, op. cit., s. 430. 
o Wielkie Jeziora Mazurskie - ubezpieczała grupa „Brandt” w składzie dwóch brygad piechoty „Lötzen” i „Gołdap”, wiążąc siły polskiej Samodzielnej Grupy Operacyjnej „Narew” na linii Pisz-Ełk-Gołdap ${ }^{29}$.

Z operacyjnego punktu widzenia, plan działania niemieckiej 3 Armii uznać należy za prawidłowy i w pełni uzasadniony co do założonych kierunków uderzeń i wydzielonych do tego sił. Główny kierunek natarcia armii prowadził jej siły najkrótszą drogą na Warszawę. Konkludując, można stwierdzić, że w 1939 r. obszar jezior mazurskich odegrał znaczącą rolę w tych planach. W oparciu o jego rozbudowę fortyfikacyjną, dokonano koncentracji sił mających za zadanie oskrzydlenie frontu polskiego. Siły niemieckiej 3 Armii zabezpieczały zarazem Prusy Wschodnie przed zaczepnymi działaniami strony polskiej oraz odgrywały znaczącą rolę w planowaniu operacyjno-taktycznym Wehrmachtu.

Opanowanie Polski jesienią 1939 r. stworzyło nową sytuację strategiczną. Po zakończeniu działań wojennych, Niemcy stworzyli nową koncepcję obrony swej granicy wschodniej, gdyż istniejący system umocnień znalazł się daleko od potencjalnej linii frontu. W 1940 r. niemieckie dowództwo określiło zespół przedsięwzięć mających na celu przygotowanie obszaru koncentracji i rozmieszczenia strategicznego Wehrmachtu do agresji na Związek Radziecki. Prace, rozpoczęte latem 1940 r., oprócz rozbudowy istniejącego systemu umocnień - objęły budowę grupy stanowisk dowodzenia dla centralnych władz państwowych i wojskowych w rejonie Wielkich Jezior Mazurskich. Dla ich osłony planowano wybudować polową pozycję (z elementami fortyfikacji stałej) w centrum prowincji (w obszarze jezior mazurskich), obejmującą m.in. umocnienia Kanału Mazurskiego, Giżyckiego Rejonu Umocnionego oraz pozycji Piska i Szczycieńska ${ }^{30}$.

Gdy zapadły pierwsze decyzje dotyczące wojny przeciw Związkowi Radzieckiemu, Hitler zażądał zbudowania umocnionej kwatery głównej w pobliżu frontu, by jako najwyższy zwierzchnik Wehrmachtu mógł szybko ingerować w operacje wojskowe i odwiedzać oddziały walczące na wschodzie. Ostatecznie na kwaterę wybrano okolice wioski Gierłoż położonej $8 \mathrm{~km}$ na północny wschód od Kętrzyna ${ }^{31}$. Już 19 grudnia 1940 r. Hitler nakazał szybkie wzniesienie dobrze umocnionej kwatery dowodzenia, zabezpieczonej przed atakiem sił powietrznodesantowych. Jej budowa miała zostać zakończona do kwietnia 1941 r. Dla dowództw i najwyższych dostojników, takich jak Ribbentrop i Himmler - planowano zbudować oddzielne kwatery.

29 W.B. ŁACH, System obronny na Warmii..., s. 56.

${ }^{30}$ Ibidem, s. 87-88; K. Dieckert, H. Grossman, op. cit., s. 51-52; M. Rogalski, M. ZaborowsKI, op. cit., s. 338.

31 W.B. ŁACH, Niemieckie kwatery dowodzenia w obszarze Wielkich Jezior Mazurskich w systemie militarnym III Rzeszy niemieckiej, [w:] Dzieje militarne Krainy..., s. 107-108. 


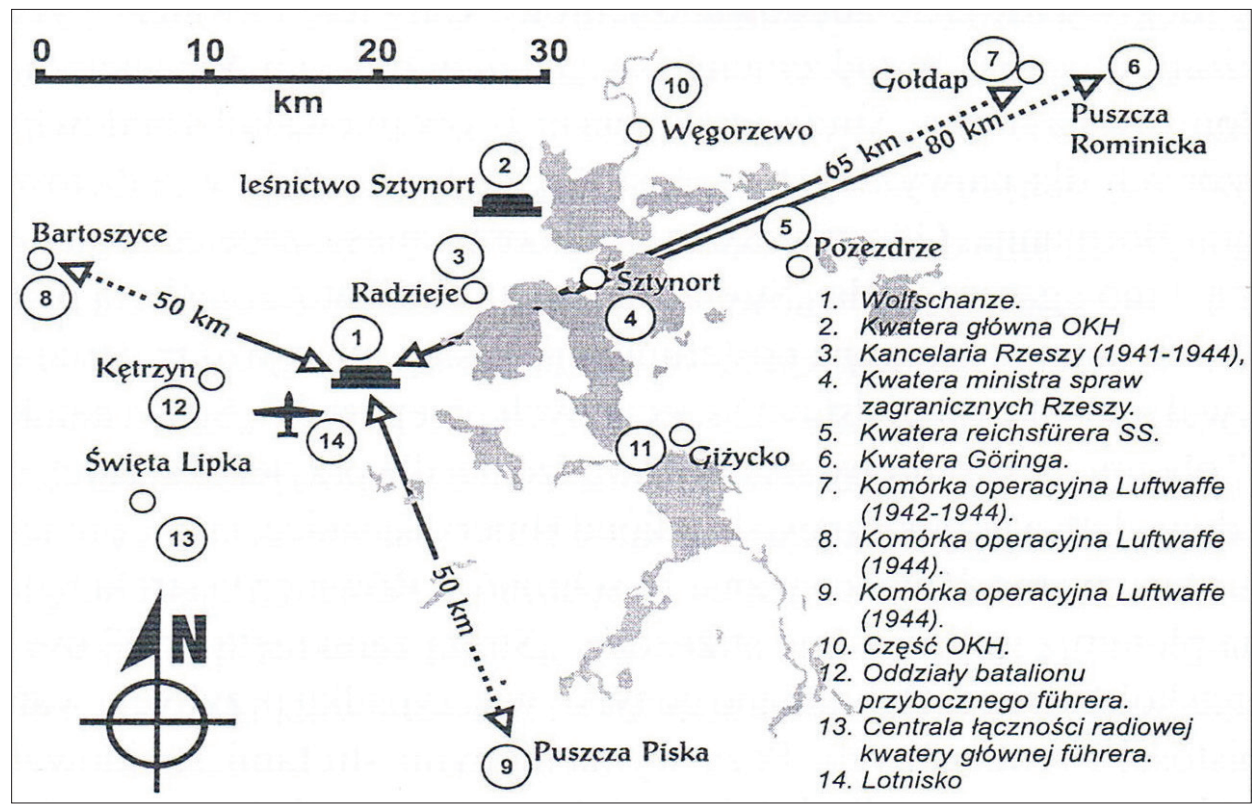

Mapa 1. Niemieckie kwatery dowodzenia w obszarze Wielkich Jezior Mazurskich Źródło: W.B. ŁACH, System obronny na Warmii i Mazurach w czasie II wojny światowej, Węgorzewo 2002, s. 89.

Decyzję o budowie stanowisk dowodzenia podjęto z uwagi na korzystne warunki terenowe w rejonie Wielkich Jezior Mazurskich. Były one przy tym znakomicie maskowane z zastosowaniem dodatkowych środków ochronnych. Wysoki las i gęste poszycie oraz jeziora stanowiły kolejne zabezpieczenie. Sprawną komunikację zapewniały liczne lotniska polowe oraz bezpośrednie połączenia kolejowe i drogowe. Ochronę kwater stanowiły fortyfikacje rejonów umocnionych. Dla Hitlera i jego najbliższego otoczenia zbudowano od podstaw kompleks bunkrów przeciwlotniczych i baraków mających obudowę przeciwodłamkową. Na lokalizację stanowisk dowodzenia wpływ miała dyrektywa Hitlera nr 16 z 16 lipca 1940 r., która nakazywała sztabom naczelnych dowódców wojsk lądowych, marynarki wojennej i lotnictwa rozmieszczenie kwater w odległości nie większej niż $50 \mathrm{~km}$ od kwatery głównej ${ }^{32}$.

Kwatera, której Hitler po wprowadzeniu się nadał nazwę Wilczy Szaniec (Wolfschanze), składała się z jego kwatery głównej, jako najwyższego zwierzchnika Wehrmachtu, ulokowanej w lasach Gierłoży, oraz z licznych kwater pobocznych”. Na północ od kwatery głównej, w okolicy leśnictwa Sztynort nad

32 W.B. ŁACH, System obronny na Warmii..., s. 90. 
Mamrami, a także w Martianach koło Węgorzewa została zbudowana kwatera Dowództwa Wojsk Lądowych (OKH). Natomiast sztab dowództwa Luftwaffe znajdował się w Szerokim Borze (6 km na zachód od Pisza) i Gołdapi, punkt dowodzenia reichsführera SS - w lasach pod Pozezdrzem (około $20 \mathrm{~km}$ na północny wschód od Wilczego Szańca), minister spraw zagranicznych - rezydował we dworze dóbr Sztynort, zaś szef Kancelarii Rzeszy - w Radziejach (kilka kilometrów od Gierłoży). Ponadto, OKH zajęła koszary w Węgorzewie i Giżycku oraz nowo zbudowany, obszerny obóz barakowy z niewielkimi bunkrami betonowymi nad Mamrami. Dla sztabu dowodzenia Luftwaffe i dla reichsführera SS zostały wybudowane zamaskowane bocznice kolejowe dla pociągów specjalnych, a także baraki i kilka mniejszych bunkrów. Zabudowania dworskie w Sztynorcie dla ministra spraw zagranicznych specjalnie powiększono i wyremontowano ${ }^{33}$.

Wybuch wojny ze Związkiem Radzieckim stworzył całkowicie odmienną sytuację, w porównaniu z przeprowadzonymi wcześniej kampaniami, gdyż rozmach działań przerastał wszystko, z czym niemieckie dowództwo i niemieckie siły zbrojne uprzednio się zetknęły. Wysiłek skupiony na froncie wschodnim, obliczony na krótkotrwały okres, nie przyniósł rozstrzygnięcia i front ten już do końca wojny angażował główne siły niemieckiej armii ${ }^{34}$.

Pozycje i rejony umocnione nabrały ponownie znaczenia w drugiej połowie 1944 r., kiedy to Armia Czerwona zbliżyła się do Prus Wschodnich. Niemcy intensywnie przygotowując się do ich obrony, rozbudowywali i umacniali system umocnień, które miały powstrzymać lub przynajmniej spowolnić ruch wojsk sowieckich. Jedną z takich fortyfikacji był Giżycki Rejon Umocniony, który rozszerzono dalej na zachód, włączając do niego zbudowane w pobliżu stanowiska dowodzenia III Rzeszy. Z tych względów rejon ten był utrzymywany w stałej gotowości i stanowił główny trzon obrony jezior mazurskich. W tym momencie spełniał samodzielne funkcje taktyczno-operacyjne, a w połączeniu z umocnieniami nad Kanałem Mazurskim - nabrał znaczenia obronno-zaczepnego. Kwatery dowodzenia na obszarze Wielkich Jezior Mazurskich - po ewakuacji Hitlera i jego najbliższych współpracowników, były wykorzystywane na przełomie 1944 i 1945 r. przez sztab niemieckiej 4 Armii $^{35}$.

Przygotowywana od wielu miesięcy ofensywa zimowa Armii Czerwonej na froncie od Bałtyku do Karpat ruszyła 12 stycznia 1945 r. Wojska 3 Frontu Białoruskiego nacierały na tym samym kierunku operacyjnym, co carska 1 Armia w 1914 r., lecz charakter natarcia był zupełnie inny. Wojska Frontu, łamiąc opór Niemców, posuwały się na zachód, nie pozwalając na jakiekolwiek działania manewrowe dywizjom niemieckim. Oddziały niemieckiej 4 Armii, zgodnie

\footnotetext{
${ }^{33}$ F.W. Zeidlen, D. Zelgert, Kwatery Główne Führera, Warszawa 2001, s. 210.

${ }^{34}$ T. SAWICKI, Niemieckie wojska lądowe na froncie wschodnim, Warszawa 1987, s. 25.

35 W. Rużewicz, op. cit., s. 85.
} 
z planem - w nocy z 21 na 22 stycznia wycofały się do umocnionego rejonu jezior mazurskich. Ataki Rosjan na Giżycko zaczęly się 24 stycznia. Przedpola miasta broniły jednostki piechoty, saperów, zapasowe pododdziały artylerii i szkolne. Rosjanie z wolna zdobywali teren i 26 stycznia pokonali jeziora po lodzie na południe i na północ od twierdzy Boyen i w ten sposób wyszli na tyły obrońców. Walki, szczególnie w rejonie wspomnianej twierdzy, trwały jeszcze przez cały dzień. Wieczorem jednostki niemieckie otrzymały rozkaz opuszczenia bronionych pozycji w Giżycku i wycofania się na zachód ${ }^{36}$.

Działania 2 Frontu Białoruskiego, który zbliżył się od południa do Elbląga - stawiały dowództwo Grupy Armii „Środek” w coraz trudniejszej sytuacji. Hitler odrzucił ponawianą przez gen. Georga-Hansa Reinhardta usilną prośbę o zezwolenie na odejście 4 Armii na zachód. Mimo to, wspomniany generał podjął decyzję o jej wycofaniu za linię fortyfikacji Giżyckiego Rejonu Umocnionego, nie chcą doprowadzić do okrążenia tego związku operacyjnego. Dowodzący 4 Armią - gen. Friedrich Hossbach - przerażony obchodzącymi go z obu stron klinami Armii Czerwonej, podjął próbę przebicia się na zachód w celu jak najszybszego opuszczenia terenu Prus Wschodnich. W konsekwencji obaj dowódcy zostali odwołani ze stanowisk i oskarżeni o niewykonanie rozkazów obrony jezior za wszelką cenę $e^{37}$. W tym też czasie, saperzy niemieccy próbowali wysadzić w dniach 24-26 stycznia Wilczy Szaniec. Z powodu pośpiechu i małej ilości ładunków wybuchowych zadanie wykonali tylko częściowo, natomiast kwatery dowództwa wojsk lądowych w Przystani i wojsk lotniczych w Szerokim Borze - z powodu szybko nadciągającego frontu - pozostały niezniszczone.

Chociaż umocnienia jezior mazurskich odpowiadały współczesnym koncepcjom prowadzenia działań wojennych, a budowle obronne były zmodernizowane - to jednak zostały przełamane przez wojska 3 Frontu Białoruskiego, których szybkość działania nie pozwoliła Niemcom na wykorzystanie przygotowywanych przeszkód i organizację skutecznej obrony, nie mówiąc o wykonaniu jakiegokolwiek przeciwuderzenia. Niewątpliwie, jedną z przyczyn przełamania zapór jezior mazurskich przez Armię Czerwoną stała się zimowa pora, gdyż dzięki temu naturalne przeszkody były zamarznięte i wiele ataków przeprowadzono, wykorzystując tafle lodowe jezior.

\section{Jeziora mazurskie w systemie obronnym Polski po II wojnie światowej}

W momencie przejęcia w 1945 r. - w wyniku postanowień konferencji poczdamskiej - południowej części Prus Wschodnich (Warmii i Mazury) przez administrację polską należało zabezpieczyć poniemiecką infrastrukturę wojskową.

\footnotetext{
${ }^{36}$ K. Dieckert, H. Grossmann, op. cit., s. 144.

37 Ibidem, s. 145-146.
} 
Paradoksalnie wszystkie obiekty koszarowe w obszarze jezior mazurskich znajdowały się $\mathrm{w}$ dobrym stanie, mimo działań wojennych i szabrownictwa powojennego. Były to nowoczesne obiekty $\mathrm{z}$ dobrze rozbudowanym zapleczem szkoleniowym dla różnych rodzajów wojsk. Tymczasem brak jednostek WP na Warmii i Mazurach powodował, że polska administracja nie kwapiła się do ich przejmowania $^{38}$.

Proces wykorzystywania tych obiektów przez WP rozpoczął się dopiero w sierpniu 1945 r., kiedy to obszar dawnych Prus Wschodnich włączono w skład nowo utworzonego Warszawskiego Okręgu Wojskowego. Spowodowało to stopniowy „napływ” w rejon Wielkich Jezior Mazurskich szeregu jednostek wojskowych. Pierwsze z nich przybyły w te strony tylko na okres żniw, inne w związku $\mathrm{z}$ podjęciem krótkoterminowych prac, związanych $\mathrm{z}$ rozminowaniem terenu i zabezpieczeniem istniejących fortyfikacji, jeszcze inne na czas swej demobilizacji. Większość jednostek, które rozlokowano w Giżycku i Orzyszu, wchodziła w skład 18 Dywizji Piechoty ${ }^{39}$.

Sposób użycia jednostek WP w okresie tzw. Polski Ludowej - w przypadku konfrontacji zbrojnej wyznaczała strona sowiecka w kontekście własnych zadań strategiczno-operacyjnych. Ona także określała charakter wykorzystania terytorium Polski, jako teatru działań wojennych. Można przyjąć, że ze względu na znaczne oddalenie omawianego obszaru od linii styczności z ewentualnym przeciwnikiem, nie przewidywano wóczas dla obszaru jezior mazurskich zadań o znaczeniu priorytetowym, a co najwyżej wspomagającym - o czym świadczyło stacjonowanie tu głównie jednostek drugiego rzutu i zapasowych ${ }^{40}$. Tak więc obszar jezior mazurskich - po raz pierwszy w historii XX w. - po zakończeniu II wojny światowej nie miał dla strategów wojskowych istotniejszego znaczenia. Stał się on miejscem dyslokacji własnych jednostek odwodowych oraz zapleczem mającym stanowić w wypadku konfliktu zbrojnego rejon koncentracji dla wojsk nadchodzących z głębi Związku Radzieckiego ${ }^{41}$.

Wraz z zakończeniem działań militarnych zarówno administracja cywilna, jak i wojskowa, stanęła przed problemem dalszego wykorzystania poniemieckich fortyfikacji, a także ich rozminowania. Problemy te stały się priorytetowe dla wojsk inżynieryjnych, które przejęły dawne obiekty fortyfikacyjne w systemie Giżyckiego Rejonu Umocnionego. Ważniejsze poniemieckie fortyfikacje stałe na terenie jezior mazurskich znajdowały się w obszarze linii obronnej, biegnącej

38 L. KowALSKI, Proces przejmowania byłych ziem Prus Wschodnich w granice państwa polskiego. Aspekty polityczno-gospodarczo-militarne, [w:] Działania militarne w Prusach Wschodnich, red. W. WróbleWski, Warszawa 1998, s. 362.

3915 Giżcka Brygada..., s. 73, 81.

40 CAW-WBH, SG WP, sygn. IV.501.1/A.706, Opis dróg samochodowych na terenie Polski według stanu na 1 I 1947 r., brak paginy.

${ }^{41}$ L. Kowalski, op. cit., s. 366-367. 
na odcinku Szczytno-Pisz-Orzysz-Węgorzewo-Gołdap. Ponadto, oprócz wymienionych wyżej ufortyfikowanych rubieży typu stałego, w Krainie Wielkich Jezior Mazurskich znajdowało się wiele umocnień specjalnego przeznaczenia. Były to mniej lub bardziej rozbudowane stanowiska dowodzenia (np. kwatera Adolfa Hitlera koło Kętrzyna), magazyny oraz inne obiekty różnego charakteru i przeznaczenia ${ }^{42}$.

Zadaniem pierwszoplanowym było przeprowadzenie niezbędnego rozpoznania, lokalizacji tych obiektów oraz ich zinwentaryzowanie. W stosunku do obiektów, które uznano za najważniejsze z punktu widzenia obronności kraju, podjęto decyzje o ich konserwacji i ochrony. $Z$ fortyfikacji stałych wojsko przejęło do dalszego wykorzystania obiekty znajdujące się na orzyskim poligonie, na skład amunicji przeznaczono kwaterę Luftwaffe znajdującą się w Szerokim Borze, w Giżycku w całości przejęto rejon twierdzy Boyen, a w Martianach zabezpieczono i ochraniano kwaterę Dowództwa Wojsk Lądowych. Kwaterę Adolfa Hitlera ze względu na zniszczenia postanowiono przekazać władzom cywilnym ${ }^{43}$.

O ile okres pierwszej połowy lat pięćdziesiątych charakteryzował się znacznym wzrostem zainteresowania problematyką fortyfikacyjną ze względu na zaostrzenie się sytuacji międzynarodowej, o tyle później zaczęły przeważać teorie, iż przyszłe pole walki nie będzie posiadało stabilnego charakteru, jak to było dotychczas, lecz cechować się będzie wyjątkową dynamiką i manewrowością. Zaczęto coraz bardziej preferować fortyfikacje polowe, które mogły być stosowane powszechnie. Zdecydowano, że jedynie w momencie potęgowania zagrożenia głównym obszarem intensywnej rozbudowy fortyfikacyjnej zostanie cały pas wybrzeża. Jednak najwięcej poniemieckich obiektów fortyfikacyjnych, które można przystosować i wykorzystać w nowej sytuacji znajdowało się w obszarze jezior mazurskich. Podjęto więc decyzję o demontażu części z nich i przerzuceniu nad morze ${ }^{44}$.

Utrata znaczenia operacyjnego nie oznaczała, że Kraina Wielkich Jezior Mazurskich przestała być istotna dla polskiego dowództwa. Wręcz odwrotnie, w wyniku zaostrzenia sytuacji międzynarodowej (wojna w Korei) zaczęto dyslokować tam liczne jednostki - ze względu na wspomnianą już bazę szkoleniową, a szczególnie poniemiecki poligon w Orzyszu, który stał się niezbędny do szkolenia wojsk. W rozkazie z 8 września 1945 r. naczelny dowódca WP nakazał utworzyć Okręgowy Poligon Artyleryjski w Orzyszu - w oparciu o etat nr 4/13 (obsada stała: 23 żołnierzy i 3 pracowników kontraktowych) ${ }^{45}$. Nazwa jednostki i etat zmieniał się kilkakrotnie. Początkowo, od 8 maja 1947 r. był to Centralny Poligon Artylerii nr 3,

${ }^{42}$ CAW-WBH, SG WP, sygn. IV.501.1/A.706, Pasy obronne od strony zachodniej, brak paginy.

${ }^{43}$ CAW-WBH, SG WP, sygn. IV.510.1/A.1543, Sprawozdanie obiektów fortyfikacyjnych drugiej kolejności na terenie Warszawskiego Okręgu Wojskowego, brak paginy.

${ }^{44}$ CAW-WBH, SG WP, sygn. IV.510.1/A.1627, Przeprowadzenie konserwacji i rozpoznania obiektów fortyfikacyjnych na odcinkach nr 1-8 oraz w rejonie Prostek, brak paginy.

${ }^{45}$ http://ospwlorzysz.wp.mil.pl/ [dostęp: 10 VIII 2019 r.]; W. BrendA, op. cit., s. 163; 
zaś 8 sierpnia 1970 r. otrzymał nazwę: Ośrodek Szkolenia Poligonowego Wojsk Lądowych. Od 1 lipca 2007 r. znajdował się w strukturach Dowództwa Wojsk Lądowych, a obecnie podlega Dowództwu Generalnemu Sił Zbrojnych ${ }^{46}$.

Pod koniec lat czterdziestych w obszar jezior mazurskich zaczęły przybywać jednostki artyleryjskie. W czerwcu 1948 r. został sformowany pułk artyleryjskiego rozpoznania pomiarowego w Orzyszu ${ }^{47}$. W maju 1949 r. rozpoczęto organizację w Węgorzewie nowej 15 Brygady Artylerii Ciężkiej złożonej z 1131 żołnierzy, 40 dział, 52 samochodów i 49 ciągników artyleryjskich ${ }^{48}$. Wiosną 1951 r., niepewna sytuacja międzynarodowa wymusiła wprowadzenie planu przyśpieszonego rozwoju wojska, czego efektem była sformowana 8 Dywizja Artylerii Przełamania z dowództwem w Orzyszu (liczyła 6 tys. żołnierzy, 280 dział, 383 samochodów i 289 ciągników artyleryjskich). Od tego momentu obszar jezior mazurskich zaczął ponownie nabierać charakterku operacyjnego, gdyż tworzona dywizja miała działać na rzecz 8 Korpusu Piechoty (w późniejszym okresie Korpus Armijny) z dowództwem w Olsztynie ${ }^{49}$. W jego skład wchodziły: dowództwo dywizji, bateria dowodzenia, 26 Brygada Artylerii Haubic z Orzysza, 29 Brygada Artylerii Haubic z Bemowa Piskiego, 15 Brygada Artylerii Ciężkiej i dywizjon artyleryjskiego rozpoznania pomiarowego $\mathrm{z}$ Węgorzewa. W czerwcu 1953 r. utworzono dodatkowo 24 Brygadę Moździerzy Ciężkich w Orzyszu. Równocześnie rozpoczęto rozbudowę 8 Dywizji Artylerii Przełamania, zwiększając liczbę brygad artylerii haubic $\mathrm{z}$ dwóch do czterech (sformowano nową 32 Brygadę Artylerii Haubic i 34 Brygadę Artylerii Haubic Ciężkich). Lata pięćdziesiąte to ciągłe zmiany organizacyjne dywizji. Ostatnia miała miejsce w październiku 1958 r., kiedy 8 Dywizję Artylerii Przełamania przemianowano na dywizję artylerii, a 32 Brygadę Artylerii Haubic i 24 Brygadę Moździerzy Ciężkich w znacznym stopniu skadrowano. W 1960 r. sztab dywizji przeniesiono do Giżycko, a rok później 30 października dywizję rozwiązano ${ }^{50}$.

Znowelizowany Plan zamierzeń organizacyjnych Wojska Polskiego na lata 1959-1965 zakładał wprowadzenie na uzbrojenie rakiet klasy „ziemia-ziemia”, a jednocześnie dalsze wydatne (niemal o jedną czwartą) ograniczenie jednostek artylerii ${ }^{51}$. Zgodnie z planem zamierzeń na rok 1962, wyznaczono bazę formowania

${ }^{46}$ http://ospwlorzysz.wp.mil.pl/ [dostęp: 13 VIII 2015 r.].

${ }^{47}$ CAW-WBH, SG WP, sygn. IV.501.1/A.164, Rozkaz organizacyjny ministra Obrony Narodowej nr 0120/Org. z 10 VI 1948 r., brak paginy.

${ }^{48}$ CAW-WBH, SG WP, sygn. IV.501.1/A.178, Rozkaz organizacyjny ministra Obrony Narodowej nr 081/Org. z 24 VII 1950 r. i nr 0100/Org. z 2 IX 1950 r., brak paginy.

${ }_{49}$ L. Grot, T. Konecki, E. Nalepa, Pokojowe dzieje Wojska Polskiego, Warszawa 1988, s. 59.

${ }^{50}$ Archiwum Wojskowe w Nowym Dworze Mazowiecki, sygn. 4004/10/19, Teczka dokumentacji likwidacji Sztabu 8 Dywizji Artylerii, brak paginy.

${ }^{51}$ Stosownie do właściwości sprzętu oraz instrukcyjnych zasad działań bojowych ogólnowojskowych związków taktycznych i operacyjnych na atomowym polu walki tworzono: w dywizjach zme- 
pierwszych jednostek rakietowych. Przyjęto propozycję sztabu artylerii WP, by stał się nią garnizon Orzysz. Za takim rozwiązaniem przemawiał szereg argumentów, gdyż znajdowała się tam duża grupa kadry artyleryjskiej z rozformowywanych i zredukowanych do pułków i samodzielnych dywizjonów brygad 8 Dywizji Artylerii, zaś orzyski garnizon dysponował dobrą bazą koszarową oraz zapleczem przystosowanym do obsługi licznego sprzętu technicznego. Ważnym atutem była także bliskość dużego, praktycznie bezpośrednio przylegającego do koszar, poligonu. Dostateczna była też komunikacja kolejowa i drogowa, a jednocześnie położenie miasta ułatwiało maskowanie i ochronę kontrwywiadowczą głęboko utajnionych jednostek. Równocześnie z decyzjami organizacyjnymi, rozpoczęto prace adaptacyjne w obiektach koszarowych oraz budowę nowych budynków mieszkalnych dla kadry.

Brygada, nosząca oficjalne miano 32 Łużyckiej Brygady Artylerii, została sformowana w oparciu o kadrę dawnej 32 Brygady Artylerii Haubic. Zasadniczymi oddziałami nowej brygady były dwa dywizjony rakiet operacyjno-taktycznych. Przygotowanie i przeprowadzenie startów rakiet wymagało doskonałego przygotowania indywidualnego wszystkich żołnierzy - toteż zadanie to otrzymała druga orzyska jednostka wojsk rakietowych - Ośrodek Szkolenia Artylerii, powołany wraz z 32 Łużycką Brygadą Artylerii. Zadaniem ośrodka było szkolenie artylerzystów oraz przygotowanie kadr dla mających powstać kolejnych brygad rakiet operacyjno-taktycznych. Operacyjne zadania 32 Brygady Artylerii (przemianowanej później na 32 Brygadę Rakiet Operacyjno-Taktycznych) nie zmieniały się zasadniczo w całym okresie jej istnienia. Była ona szkolona do wykonania uderzenia jądrowego na szczeblu armijnym. Jej atutem przed wykryciem miały być lasy i jeziora, które dawały możliwość zajęcia stanowisk startowych. Wymagało to jednak utrzymania wysokiej gotowości i zdolności bojowej. Dnia 22 listopada 1988 r. Prezydium Komitetu Obrony Kraju zaakceptowało przedstawiony przez Ministerstwo Obrony Narodowej program restrukturyzacji, który m.in. zakładał nadanie siłom zbrojnym obronnego charakteru, co wiązało się z wycofaniem $\mathrm{z}$ ich struktur organizacyjnych uzbrojenia o wyraźnie zaczepnym charakterze. $Z$ funkcjonujących brygad rakietowych, jako pierwszą planowano zlikwidować brygadę w Orzyszu. Rozformowaniu miały również ulec 1 Warszawska Brygada Artylerii Armat, stacjonująca w Węgorzewie ${ }^{52}$. Ostatecznie, w wyniku zamierzeń restrukturyzacyjnych, zarządzeniem Szefa SG WP z dnia 28 lutego 1989 r. w sprawie rozformowania określonych związków taktycznych

chanizowanych i pancernych - dywizjony rakiet taktycznych liczące 3-4 wyrzutnie, zaś na szczeblu armii i frontu - brygady rakiet operacyjno-taktycznych w składzie 6 lub 9 wyrzutni.

${ }^{52}$ W. Pietrzak, Brygada w okresie wielkich zmian, [w:] Garnizony artyleryjskie na Warmii i Mazurach, cz. II, Artyleria polska w XX wieku. W 70 rocznicę powstania 1 Warszawskiej Brygady Artylerii Armat im. gen. J. Bema w Węgorzewie, red. W.B. ŁACH, Węgorzewo 2014, s. 196. 
i oddziałów - z dniem 31 października tego roku przestała istnieć 32 Brygada Rakiet Operacyjno-Taktycznych, natomiast na bazie 1 Brygady Artylerii Armat - powstał 1 Ośrodek Szkolenia Specjalistów Wojsk Rakietowych i Artylerii53.

\section{$* * *$}

Wraz z rozwiązaniem 32 Brygady Rakiet Operacyjno-Taktycznych i 1 Brygady Artylerii Armat - kończy się okres ofensywnego wykorzystania obszaru Wielkich Jezior Mazurskich w ramach Układu Warszawskiego. Jednocześnie lata 1989-1991 upłynęły pod znakiem zabiegów o uzyskanie pełnej suwerenności, czyli o wyjście z dotychczasowej zależności militarnej od Związku Radzieckiego. Trzeba jednak zaznaczyć, że te działania nie przekładały się na rozwiązania systemowe, które dałyby możliwość innego spojrzenia na obszar operacyjny, jakim były Wielkie Jeziora Mazurskie. Wręcz odwrotnie - rozformowano szereg jednostek wojskowych (często w sposób nieprzemyślany), a z braku środków finansowych rezygnowano z prowadzenia zajęć taktycznych i dostaw nowego sprzętu.

Dopiero w połowie lat dziewięćdziesiątych zaczęto patrzeć zupełnie inaczej na pas jezior mazurskich. Położenie blisko granicy z Rosją spowodowało, że zrobiono remanent fortyfikacji poniemieckich i obiektów wojskowych, zaś Wielkie Jeziora Mazurskie zaczęto traktować jako oś ewentualnych działań operacyjno-taktycznych w obszarze Polski północnej.

W ramach planowania wojennego, opracowano w 1996 r. strategiczny plan obrony Rzeczpospolitej Polskiej. Był to pierwszy tego typu dokument zawierający ocenę zagrożeń wojennych oraz myśl przewodnią obrony Polski związaną z sytuacją polityczno-gospodarczą po rozpadzie Związku Radzieckiego. Zakładano, że strategicznym celem obrony będzie zmuszenie przeciwnika do zaniechania ataku przez stawianie jak najdłużej regularnego i nieregularnego oporu zbrojnego, mającego zadać agresorowi maksymalne straty oraz stworzyć przesłanki do późniejszej kontrakcji. W wypadku wkroczenia przeciwnika na teren Warmii i Mazur zakładano, że osią obrony staną się Wielkie Jeziora Mazurskie, a podstawą do przeciwnatarcia będzie obszar Orzysz (poligon) - Pisz (Puszcza Piska). Przewidywano, że w chwili przystąpienia Polski do NATO plan obrony państwa całkowicie się zmieni i będzie dostosowany do nowych warunków obrony koalicyjnej. O wiele łatwiej było opracować plany, niż odpowiednio przygotować region Warmii i Mazur, a tym samym obszar jezior mazurskich - do działań operacyjnych. Żeby powtórnie odkryto znaczenie tego obszaru do działań obronnych i ofensywnych przy wsparciu sojuszniczym, musiały minąć jeszcze dwie dekady.

${ }^{53}$ Archiwum Wojskowe w Nowym Dworze Mazowieckim, sygn. 1272/96/271, Teczka nr 64/III - zarządzenie Szefa SG WP nr 023/org. z dnia 28 II 1989 r. w sprawie rozformowania Wojsk Rakietowych i Artylerii; W. Pietrzak, op. cit., s. 197. 


\section{Wiesław Bolesław Łach}

\section{EXPERIENCES AND CONCLUSIONS FROM THE MILITARY USE OF THE GREAT MASURIAN LAKES AREA IN THE 20 ${ }^{\text {TH }}$ CENTURY}

Summary: In the eastern part of the Warmian-Masurian Voivodeship, lies the Land of the Great Masurian Lakes. The line of these lakes during the First World War crossed the roads leading from the east into the German Reich, forcing the Russian army to circumvent it in 1914 and contributed to their defeat. In 1915, this entire natural defensive line was modernized and was ready for combat. However, in the interwar period it was additionally strengthened with a new fortification system. In 1940, the work started, in addition to expanding the existing fortification system, included the construction of a group of command posts for central state and military authorities (including headquarters for Adolf Hitler near Kętrzyn). In 1944, Germany prepared intensively for defense, expanding its fortification system, hoping that Masurian lakes would become the axis of defense. However, the nature of the combat operations in 1945 differed fundamentally from the 1914 fights. The Red Army broke the fortifications of the German defensive lines by maneuvering and destroying the areas of resistance. After the World War II, the lake area was within the Polish state. The army took over Göring's headquarters in Broad Bor creating ammunition stores. The training ground in Orzysz and barracks facilities were used to locate military units in Węgorzewo and Giżycko. In the 1960 s, using the natural conditions of the lakes, the $32^{\text {nd }}$ Brigade of operational-tactical missiles was located in Orzysz. The close location of the Polish border with Russia in the 1990s meant that a German inventory of German fortifications and military facilities was carried out, and the Great Masurian Lakes are treated as an axis of possible tactical operations in northern Poland. The character of stationed units, which are operational in nature, has changed, and the training ground in Orzysz has become the base of allied forces.

Keywords: experiments, fortifications, Masurian lakes, army, conclusions. 